\title{
Copper and Cyanide Recovery in Cyanidation Effluents
}

\author{
José R. Parga ${ }^{1}$, Jesús L. Valenzuela ${ }^{2}$, Héctor Moreno ${ }^{3}$, Jaime E. Pérez ${ }^{1}$ \\ ${ }^{1}$ Department of Metallurgy and Materials Science, Institute Technology of Saltillo, Saltillo, México \\ ${ }^{2}$ Departament of Chemistry and Metallurgy, University of Sonora, Hermosillo, México \\ ${ }^{3}$ Chemistry Department, Institute Technology of Laguna, Torreón, México \\ E-mail: jrparga@its.mx \\ Received August 26, 2011; revised September 13, 2011; accepted September 23, 2011
}

\begin{abstract}
Cyanidation is the main process for gold and silver recovery from its ores. In this study, a process is proposed to recover copper and cyanide from barren solutions from the Merrill-Crowe cementation process with zinc dust. This technology is based on inducing nucleated precipitation of copper and silver in a serpentine reactor, using sodium sulfide as the precipitator, and sulfuric acid for $\mathrm{pH}$ control. Results show that $\mathrm{pH}$ value has a significant effect on copper cyanide removal efficiency, and it was determined the optimal $\mathrm{pH}$ range to be 2.5 - 3. At this $\mathrm{pH}$ value, the copper cyanide removal efficiency achieved was up to $97 \%$ and $99 \%$, when copper concentration in the influent was 636 and $900 \mathrm{ppm}$. respectively. In this process (sulphidization-acidification-thickening-HCN recycling), the cyanide associated with copper cyanide complexes, is released as HCN gas under weakly acidic conditions, allowing it to be recycled back to the cyanidation process as free cyanide. Cyanide recovery was $90 \%$. Finally, this procedure was successfully run at Minera William in México.
\end{abstract}

Keywords: Precipitation, Cyanide Removal, Copper Recovery, Cyanidation

\section{Introduction}

Actually, the most common process for gold and silver recovery from ores is cyanidation, due to the selectivity of free cyanide for both metals, and the stability of the cyanide complex $\left(\mathrm{Au}(\mathrm{CN})_{2}^{-}, \mathrm{k}=2 \times 10^{38}\right)[1]$. Chemical recovery of gold from Merrill-Crowe process cyanide solution, involves two different operations: 1) gold dissolution, where it is oxidized and dissolved to form $\mathrm{Au}(\mathrm{I})$ ion and cyanide complex $\mathrm{Au}(\mathrm{CN})_{2}^{-}$, and 2) precipitation by reduction of metallic gold. In the cyanidation process, free cyanide ions in solution can only be provided at a $\mathrm{pH}$ of 9.0. The $\mathrm{pH}$ of the pulp can be increased adding alkalis (e.g. $\mathrm{Ca}(\mathrm{OH})_{2}, \mathrm{NaOH}$, etc.), known as protective alkalis. It is accepted that gold dissolution in cyanide solutions occurs as a sequence of two reactions, as shown in Equations (1) and (2). These reactions apply to silver as well.

$$
\begin{aligned}
& 2 \mathrm{Au}+4 \mathrm{NaCN}+\mathrm{O}_{2}+2 \mathrm{H}_{2} \mathrm{O} \rightarrow 2 \mathrm{Na}\left[\mathrm{Au}(\mathrm{CN})_{2}\right] \\
&+2 \mathrm{NaOH}+\mathrm{H}_{2} \mathrm{O}_{2} \\
& 2 \mathrm{Au}+4 \mathrm{NaCN}+\mathrm{H}_{2} \mathrm{O}_{2} \rightarrow 2 \mathrm{Na}\left[\mathrm{Au}(\mathrm{CN})_{2}\right]+2 \mathrm{NaOH}
\end{aligned}
$$

Elsner's Equation (1) shows that oxygen is critical for the dissolution of gold. Stoichiometry of the process shows that 4 moles of cyanide are needed for each mole of oxygen present in solution. At room temperature and standard atmospheric pressure, approximately $8.2 \mathrm{mg}$ of oxygen are present in one liter of water. This corresponds to $0.27 \times 10^{-3} \mathrm{~mol} / \mathrm{L}$. The corresponding sodium cyanide concentration for a complete reaction (molecular weight of $\mathrm{NaCN}=49$ ) should be equal to $4 \times 0.27 \times 10^{-3}$ $\times 49=0.05 \mathrm{~g} / \mathrm{L}$ or approximately $0.01 \%$. This was confirmed in practice at room temperature by a very dilute solution of $\mathrm{NaCN}$ of $0.01 \%-0.5 \%$ for ores, and $0.5 \%$ $5 \%$ for gold and silver concentrates [2]. Gold dissolution is an electrochemical reaction in which oxygen takes up electrons at one section of the metallic surface [cathodic zone], while the metal gives them up in another section [anodic zone]. Details of this electrochemical reaction have received considerable attention and under certain circumstances the reaction is limited by the coupled diffusion of $\mathrm{CN}^{-}$and $\mathrm{O}_{2}$ to the gold surface. Dissolution rate is normally mass-transport controlled in cyanide solutions and the activation energy is $8-20 \mathrm{~kJ} / \mathrm{mol}$ [3].

The concentration of cyanide used to dissolve gold in ores is typically higher than the stoichiometric ratio, due 
to the solubility of other minerals. Free cyanide produces complexes with several metallic species, especially transition metals, which show a broad variation in both stability and solubility [4]:

$$
\mathrm{M}^{2+}+\mathrm{CN}_{\mathrm{y}}^{-} \rightarrow \mathrm{M}(\mathrm{CN})_{\mathrm{y}}^{\mathrm{x}-\mathrm{y}}
$$

Many common copper minerals are soluble in the dilute cyanide solution, typical of leach conditions found in the gold cyanidation process. Minerals such as azurite and malaquite, are fast leached and soluble in dilute cyanide solutions. Enargite and chalcopyrite leach more slowly but are sufficient soluble to cause excessive cyanide loss and contamination of leach solutions with arsenic [5]. For example, in the cyanidation of malachite and azurite minerals, the copper carbonate component leaches as follows:

Malachite and Azurite (Leaching rate = Fast):

$2 \mathrm{CuCO}_{3}+8 \mathrm{NaCN} \rightarrow 2 \mathrm{Na}_{2} \mathrm{Cu}(\mathrm{CN})_{3}+2 \mathrm{Na}_{2} \mathrm{CO}_{3}+(\mathrm{CN})_{2}$

Then:

$$
(\mathrm{CN})_{2}+2 \mathrm{NaOH} \rightarrow \mathrm{NaCNO}+\mathrm{NaCN}+\mathrm{H}_{2} \mathrm{O}
$$

Some others possible reactions are shown below:

Cuprite (Leaching rate $=$ Fast):

$\mathrm{Cu}_{2} \mathrm{O}+6 \mathrm{NaCN}+\mathrm{H}_{2} \mathrm{O} \rightarrow 2 \mathrm{Na}_{2} \mathrm{Cu}(\mathrm{CN})_{3}+2 \mathrm{NaOH}$

Tenorite $($ Leaching rate $=$ Fast):

$$
\begin{aligned}
2 \mathrm{CuO}+7 \mathrm{NaCN}+\mathrm{H}_{2} \mathrm{O} \rightarrow & 2 \mathrm{Na}_{2} \mathrm{Cu}(\mathrm{CN})_{3} \\
& +2 \mathrm{NaOH}+\mathrm{NaCNO}
\end{aligned}
$$

Chalcocite $($ Leaching rate $=$ Fast $)$ :

$$
\begin{aligned}
\mathrm{Cu}_{2} \mathrm{~S}+7 \mathrm{NaCN}+\frac{1}{2} \mathrm{O}_{2}+\mathrm{H}_{2} \mathrm{O} \rightarrow & 2 \mathrm{Na}_{2} \mathrm{Cu}(\mathrm{CN})_{3} \\
& +2 \mathrm{NaOH}+\mathrm{NaCNS}
\end{aligned}
$$

Covellite (Leaching rate $=$ Fast):

$$
\begin{aligned}
2 \mathrm{CuS}+8 \mathrm{NaCN}+\frac{1}{2} \mathrm{O}_{2}+\mathrm{H}_{2} \mathrm{O} \rightarrow & 2 \mathrm{Na}_{2} \mathrm{Cu}(\mathrm{CN})_{3} \\
& +2 \mathrm{NaOH}+2 \mathrm{NaCNS}
\end{aligned}
$$

The cyanidation of $\mathrm{Cu}$ (II) minerals with the consequent formation of cynogen, $(\mathrm{CN})_{2}$ results in the loss of cyanide in the proportion of $0.5 \mathrm{~mol}$ of cyanide per mole of $\mathrm{Cu}$ (II) leached, i.e., $0.39 \mathrm{~kg} \mathrm{NaCN/kg} \mathrm{Cu} \mathrm{(II).} \mathrm{Cupric}$ cyanogen complexes are first formed and then they are broken down to the cuprous form liberating cyanogen, which in turn reacts with alkali to form cyanide and cyanate [6].

\subsection{Copper Removal after the Merrill-Crowe Process}

The presence of cyanide-soluble copper affects gold and silver recovery from the cyanide solutions. In the Merrill-Crowe process, the copper is precipitated along with gold and silver, resulting in a higher consumption of zinc dust, fluxes in the smelting of the precipitate and shorter life for crucibles. For these reasons, copper must be separated from the precious metals by digesting the silver/gold/zinc precipitated in sulfuric acid prior to smelting. This is a common practice in William Mining Co., which produces a copper sulfate acidic solution that goes to the zinc and arsenopyrite froth flotation circuit or to an iron cementation process before disposal. Cementation of copper using scrap iron is practiced when the quantity of copper makes recovery worthwhile. Also, to increase the recovery of silver and gold, with less copper, it is necessary to use conditions which result in the formation of $\mathrm{Cu}(\mathrm{CN})_{3}^{2-}$ and $\mathrm{Cu}(\mathrm{CN})_{4}^{3-}$. High $\mathrm{pH}$ values and high free-cyanide concentrations stabilize copper in solution resulting in lower levels of copper. Increment of copper in the barren solution poses serious metallurgical problems in the cyanidation circuit and it is necessary to include a process to strip the copper, prior to the gold and silver leaching step. Failure to do so will result in lower dissolution of precious metals and production of high-copper-silver/gold bullion.

This research focuses on the removal of copper before smelting the gold and silver precipitate and in prevention and/or minimization of the impact of copper in the barren solution after the filter press in the Merrill-Crowe process. Treatment of high-copper silver/gold leach solutions, before or after precious metals recovery, is focused on precipitation of copper as chalcocite $\left(\mathrm{Cu}_{2} \mathrm{~S}\right)$ and cyanide recovery.

\subsection{Cyanide and Copper Recovery Processes}

There is a growing interest for the recovery of both copper and cyanide from silver and gold barren solutions due to high cyanide consumption costs. William Mining Co. is also interested in reducing costs in this way. The cost of recovering and recycling cyanide from the barren leach solution will be lower than the cost of purchasing new cyanide. It has been almost a century since the Mills-Crowe process for cyanide regeneration was developed by the Mining Company Beneficiadora de Pachuca in México (England Patent No. 241669, 3.9.24) [7] and until today no significant changes to the process have been made. The simplest process for cyanide recycling involves acidifying the barren clarified solution ( $\mathrm{pH}$ between 2 and 5). During acidification, free cyanide 
and relatively weakly complexed cyanide $(\mathrm{Ag}, \mathrm{Cu}, \mathrm{Zn}$, $\mathrm{Fe}$ ) are converted into HCN gas, which is then volatilized by passing a stream of air bubbles through the solution. The air/HCN gas stream is scrubbed in a caustic solution in a second tower reactor to convert the HCN back into free cyanide ions for recycling [8]. In this process copper and silver are not recovered for resale. This has prompted interest to also recover copper by selective metal sulphide precipitation. The copper sulphide precipitate is then recovered by conventional clarification and filtration to produce a filter cake ( $45 \%$ to $60 \%$ $\mathrm{Cu})$ which can be shipped to a copper smelter.

Among the chemical precipitation methods, precipitation of metal hydroxides is the most conventional, but it suffers from shortcoming, such as high solubilities for some metals. Sulphide precipitation of metals is a viable alternative process for copper recovery from the barren cyanide solutions because of the possible high degree of metal removal over a broad $\mathrm{pH}$ range. However; hydrogen sulfide is odorous and highly toxic. It tends to accumulate in poorly ventilated spaces because it is heavier than air. Exposure to low level concentrations of this gas can result in eye irritation, sore throat and cough, shortness of breath, and fluid in the lungs [9]. Sulphide precipitation of metals has several advantages over hydroxide precipitation, such as low solubility, high stability of metal sulphides, fast reaction rates, better settling properties and potential for re-use of sulphide precipitates by smelting. The thermodynamic equilibrium involved in metal sulphide precipitation has been proposed as [10]:

$$
\begin{gathered}
\mathrm{H}_{2} \mathrm{~S} \stackrel{\mathrm{Kp} 1}{\longleftrightarrow} \mathrm{HS}^{-}+\mathrm{H}^{+}, \mathrm{K}_{\mathrm{p} 1}=\frac{\left[\mathrm{HS}^{-}\right]\left[\mathrm{H}^{+}\right]}{\left[\mathrm{H}_{2} \mathrm{~S}\right]}, \mathrm{pK}_{1}=6.99 \\
\mathrm{HS}^{-} \stackrel{\mathrm{Kp} 2}{\longleftrightarrow} \mathrm{S}^{2-}+\mathrm{H}^{+}, \mathrm{K}_{\mathrm{p} 2}=\frac{\left[\mathrm{S}^{2-}\right]\left[\mathrm{H}^{+}\right]}{\left[\mathrm{HS}^{-}\right]}, \mathrm{pK}_{2}=17.4 \\
\mathrm{M}^{2+}+\mathrm{S}^{2-} \leftrightarrow \mathrm{MS}_{(\mathrm{s})} \\
\mathrm{M}^{2+}+\mathrm{HS}^{-} \leftrightarrow \mathrm{MS}_{(\mathrm{s})}+\mathrm{H}^{+}
\end{gathered}
$$

These equations show that concentration of sulphur species is a strong function of $\mathrm{pH}$. The $\mathrm{pK}_{2}$ value is currently the most reliable value.

The use of sulphide precipitation process for copper and cyanide recovering after cyanidation has a key advantage, the ability to operate in the barren solution to first recover copper/silver and after that establish acidic conditions in the solution. This results in rapid release of free cyanide $\left(\mathrm{HCN}_{\mathrm{gas}}\right)$ that is easily recoverable by volatilization at lowered $\mathrm{pH}$ value.
If cyanide ions are present in the barren solution after precipitation from the Merrill Crowe process as free cyanide $(\mathrm{pKa}=9.4)$, it is possible to convert $99 \%$ of the cyanide into HCN gas by lowering the $\mathrm{pH}$ value of the solution to about 6 :

$$
\mathrm{CN}^{-}+\mathrm{H}^{+} \rightarrow \mathrm{HCN}_{(\mathrm{g})}
$$

On the other hand, if cyanide ions are present as metal-cyanide complexes, $\mathrm{pH}$ must be lowered to more acidic values to break down the complex and produce HCN gas. As an example, the weak zinc-cyanide complex (log $B_{4}=17.4$ ) breaks down completely at a $\mathrm{pH}$ close to 5 , producing zinc sulfate as an aqueous soluble species, plus HCN gas:

$$
\mathrm{Zn}(\mathrm{CN})_{4}^{2-}+2 \mathrm{H}_{2} \mathrm{SO}_{4} \rightarrow \mathrm{ZnSO}_{4(\mathrm{~s})}+4 \mathrm{HCN}_{(\mathrm{g})}+\mathrm{SO}_{4}^{2-}
$$

The copper cyanide complex does not break down completely, even in strong acid solution, unless there is an oxidant present in the solution. In the absence of an oxidant, the copper tricyanide (which is the most stable copper complex under normal cyanidation conditions: $\left.\log B_{3}=28\right)$ decomposes to form a CuCN precipitate, plus HCN gas (Equation (16)), at pH values lower than 3 . Hence, $33 \%$ of potentially recoverable cyanide is lost to the precipitate:

$$
\mathrm{Cu}(\mathrm{CN})_{3}^{2-}+2 \mathrm{H}^{+} \rightarrow \mathrm{CuCN}_{(\mathrm{s})}+2 \mathrm{HCN}_{(\mathrm{g})}
$$

Barren solution in the William Mining Co. process also contains ferrocyanide and cuprous cyanide that, a $\mathrm{pH}=4$, produces double metal cyanide precipitates such as $\mathrm{Cu}_{2} \mathrm{Fe}(\mathrm{CN})_{6}$ and $\mathrm{Cu}_{4} \mathrm{Fe}(\mathrm{CN})_{6}$ :

$$
\begin{aligned}
4 \mathrm{Cu}(\mathrm{CN})_{3}^{2-}+\mathrm{Fe}(\mathrm{CN})_{6}^{4-}+12 \mathrm{H}^{+} \rightarrow & \mathrm{Cu}_{4} \mathrm{Fe}(\mathrm{CN})_{6(\mathrm{~s})} \\
& +12 \mathrm{HCN}_{(\mathrm{g})}
\end{aligned}
$$

From the stoichiometry, it can be seen that the ferrocyanide molecule releases the third molecule of $\mathrm{CN}$ from the copper tricyanide complex. Therefore, the presence of ferrocyanide results in increased recovery of cyanide from the copper-cyanide species.

When thiocyanate is present, as it is often the case when leaching sulphide-bearing ores, insoluble CuSCN may also be responsible for copper precipitation and HCN gas formation in acid conditions, the following reaction show this behavior:

$$
\mathrm{Cu}(\mathrm{CN})_{3}^{2-}+\mathrm{SCN}^{-}+3 \mathrm{H}^{+} \rightarrow \mathrm{CuSCN}_{(\mathrm{s})}+3 \mathrm{HCN}_{(\mathrm{g})}
$$

Addition of sulphide ions $\left(\mathrm{Na}_{2} \mathrm{~S}\right)$ to the acidified cyanide solution results in the precipitation of cuprous sulphide (chalcocite), which is favored because of its extremely low solubility $\left(\mathrm{Ksp}=2.3 \times 10^{-48}\right)$ [11]. The fol- 
lowing reaction takes place:

$$
\begin{aligned}
2 \mathrm{Cu}(\mathrm{CN})_{3}^{2-}+2 \mathrm{H}_{2} \mathrm{SO}_{4}+\mathrm{H}_{2} \mathrm{~S}_{(\mathrm{g})} & \rightarrow \mathrm{Cu}_{2} \mathrm{~S}_{(\mathrm{s})}+6 \mathrm{HCN}_{(\mathrm{g})} \\
& +2 \mathrm{SO}_{4}^{2-}
\end{aligned}
$$

Stoichiometric rate of sulfide is approximately 0.25 grams $\mathrm{S}^{2-}$ per gram of copper, 0.44 grams NaHS per gram of copper or 0.61 grams $\mathrm{Na}_{2} \mathrm{~S}$ per gram of copper. However, the actual sulfide dosage required for nearcomplete copper precipitation is normally in excess of $200 \%$ due to additional ions in the barren solution. In precipitating copper, sulfide addition also results in the near-complete precipitation of silver, as shown in the following reaction:

$$
2 \mathrm{Ag}(\mathrm{CN})_{2}^{-}+\mathrm{H}_{2} \mathrm{~S}_{(\mathrm{g})} \rightarrow \mathrm{Ag}_{2} \mathrm{~S}_{(\mathrm{s})}+4 \mathrm{HCN}_{(\mathrm{g})}
$$

Based upon reactions 15 - 20, acid conditions may cause the dissociation of the complexes, due to the formation of some copper precipitate and subsequent liberation of HCN by volatilization, considering these reactions, up to $99 \%$ of copper could be recovered and HCN gas could be stripped from the barren solutions and adsorbed in an alkali solution of $\mathrm{NaOH}$. The simplified chemistry of the process is presented in the following reaction:

$$
\mathrm{HCN}_{(\mathrm{g})}+\mathrm{NaOH} \rightarrow \mathrm{NaCN}+\mathrm{H}_{2} \mathrm{O}
$$

The precipitate is a sellable copper product on its own, or can be blended with the arsenopirite flotation concentrate from the flotation sulphide plant.

\section{Materials and Methods}

Experiments were carried out on barren cyanide solution after the filter press on the Merrill Crowe process. The pregnant solution came from the cyanidation leach plant (500 ton/day), where the ores, from the Minera William mines, are a mixture of oxides and sulfides, with the copper ranging from $0.04 \%$ to $0.25 \%$ as the norm an average sample contains: $1.7 \mathrm{~g} / \mathrm{ton} \mathrm{Au}, 100 \mathrm{~g} / \mathrm{ton} \mathrm{Ag}$, $0.6 \% \mathrm{~Pb}, 0.61 \% \mathrm{Zn}, 0.12 \% \mathrm{Cu}, 2.3 \% \mathrm{Fe}$ and $2 \%$ of As. A wet screen analysis of the plant sample indicated that the granulometry was $80 \%-74 \mathrm{~m}$. The leaching practice in the plant was: leach pulps containing $40 \%$ solids over a period of 72 hours leaching at $\mathrm{Ph}=11.0, \mathrm{O}_{2}=5 \mathrm{ppm}$ and $2 \mathrm{~kg} / \mathrm{ton} \mathrm{NaCN}$; leached residue: $0.20 \mathrm{~g} / \mathrm{ton} \mathrm{Au}$ and $0.18 \mathrm{~g} / \mathrm{ton} \mathrm{Ag}$. Then, copper precipitation and cyanide regeneration experiments were performed to determine the effect of different process conditions on the solids of copper/silver sulphide produced by sulphide precipitation. Precipitation experiments were carried out in a 1 liter round-bottomed reaction vessel with ports for an overhead stirred, a gas sparger and a $\mathrm{pH}$ electrode. The $\mathrm{pH}$ meter is VWR 8005 Scientific and stirring motor with a glass impeller driven BDC 1850 CAFRAMO and cone size settler $(1000 \mathrm{ml})$. The barren solutions used had copper, silver, zinc and iron ions of varying concentration. The $\mathrm{pH}$ of the barren was adjusted to the required level with sulfuric acid and then a mixture of $\mathrm{Na}_{2} \mathrm{~S} /$ water was added. All experimental samples of the liquor and solid were taken at known times, solutions and solids from the process were separated by filtration through cellulose filter paper. The sludge from the precipitation was dried either in an oven or under vacuum at room temperature. Analysis of copper, silver, zinc, iron, and arsenic were performed by digestion of the precipitate and subsequent ICP/Atomic Emission Spectrometry determination and free cyanide content was determined directly via titration, whereas the total cyanide was measured by means of titration after distillation. At the end of the experiment, HCN volatilization reached efficiencies above $97 \%$ and the capture of cyanide gas by $\mathrm{NaOH}(1 \mathrm{M})$ solution was almost $95 \%$.

\section{Results and Discussion}

The experimental results of the copper, silver, zinc and iron precipitation as well as $\mathrm{CN}$ removal (\%) at different $\mathrm{pH}$ values are presented in Table 1.

Results show that $\mathrm{pH}$ has a significant effect on copper cyanide removal efficiency, and it was determined the optimal $\mathrm{pH}$ range to be 2.5 - 3. With these $\mathrm{pH}$ values, when influent copper concentration was $636 \mathrm{ppm}$, copper cyanide removal efficiency was $99 \%$. Some black precipitates were observed in the solution of experiments 2 to 6; which suggested the presence of copper, silver, arsenic, zinc and iron as sulphides. The presence of these sulphides was confirmed in Figure 1. The measured sample, which was collected from experiments of $\mathrm{pH} 2$, 3 and 4 (see Table 2), gives rise to peaks corresponding to covellite, esfalerite and pyrite. The size, EDAX and morphology of the solids are also shown in Figure 1 by SEM micrograph and EDAX analysis. The solids in the precipitate are spherical and approximately $100 \mathrm{~nm}$ in diameter.

The SEM micrograph confirms the excellent crystallinity of synthetic covellite (CuS) formed during the sulphide precipitation process. The EDAX chemical analysis pattern of the precipitate at different $\mathrm{pH}$ values is shown in Table 2.

Results of Table 2, indicate that $\mathrm{pH}=2$ to 3 is the best condition for the sulphide precipitation of copper, because the high recoveries $>99 \%$ of $\mathrm{Cu}$ and excellent quality. 
Table 1. Results of copper, silver, zinc and iron sulphide precipitates and CN removal at different pH values.

\begin{tabular}{|c|c|c|c|c|c|c|c|}
\hline & Ag & $\mathbf{Z n}$ & $\mathbf{C u}$ & $\mathbf{F e}$ & $\mathrm{Na}_{2} \mathrm{~S}$ (grs) & pH & CN Removal (\%) \\
\hline Feed Barren Solution(ppm) & 0.1 & 184 & 636 & 4 & $\mathbf{0}$ & 10.95 & \\
\hline Solution 1 (ppm) & 0 & 73 & 389 & 2 & 1.0 & 6 & 68 \\
\hline Precipitate $1(\%)$ & 124 & 17.60 & 44.90 & 1.2 & - & - & \\
\hline Solution 2 (ppm) & 0 & 93 & 420 & 2 & 0.5 & 6.0 & 63 \\
\hline Precipitate $2(\%)$ & 121 & 21.40 & 40.70 & 1.0 & - & - & \\
\hline Solution 3 (ppm) & 0 & 22 & 31 & 2 & 1.0 & 5.5 & 75 \\
\hline Precipitate $3(\%)$ & 114 & 11.90 & 51.70 & 1.0 & - & - & \\
\hline Solution 4 (ppm) & 0 & 8 & 0 & 0 & 1.0 & 5.0 & 80 \\
\hline Precipitate 4 (\%) & 119 & 13.4 & 51.27 & 1.0 & - & - & \\
\hline Solution 5 (ppm) & 0 & 32 & 0 & 0 & 1.0 & 4.5 & 95 \\
\hline Precipitate 5 (\%) & 138 & 9.92 & 56.34 & 0.9 & - & - & \\
\hline Solution 6 (ppm) & 0 & 54 & 0 & 0 & $1 . .0$ & 4 & 96 \\
\hline Precipitate 6 (\%) & 118 & 1.49 & 62.68 & 1.1 & - & - & \\
\hline Solution 7 (ppm) & 0 & 40 & 0 & 0 & 1.0 & 3.0 & 99 \\
\hline Precipitate 7 (\%) & 129 & 9.53 & 62.24 & 1.1 & - & - & \\
\hline Solution 8 (ppm) & 0 & 134 & 0 & 0 & 1.0 & 2.5 & 99 \\
\hline Precipitate 8 (\%) & 106 & 11.24 & 60.5 & 0.9 & - & - & \\
\hline
\end{tabular}

Table 2. EDAX analysis of solids precipitates at different $\mathrm{pH}$ values.

\begin{tabular}{ccccccc}
\hline \multirow{2}{*}{ Element } & \multicolumn{2}{c}{$\mathbf{p H}=\mathbf{2}$} & \multicolumn{2}{c}{$\mathbf{p H}=\mathbf{3}$} & \multicolumn{2}{c}{$\mathbf{p H}=\mathbf{4}$} \\
\cline { 2 - 7 } & Weight\% & Atomic\% & Weight\% & Atomic\% & Weight\% & Atomic\% \\
\hline O K & 7.69 & 20.37 & 9.64 & 24.35 & 7.73 & 20.03 \\
Na K & & & & & 2.51 & 4.52 \\
S K & 27.85 & 36.80 & 29.02 & 36.57 & 26.44 & 34.18 \\
Ca K & & & 0.60 & 0.61 & 0.45 & 0.46 \\
Fe K & 2.06 & 1.56 & 1.96 & 1.42 & 1.90 & 1.41 \\
Cu K & 43.46 & 28.98 & 41.19 & 26.19 & 39.94 & 26.06 \\
Zn K & 18.94 & 12.28 & 17.58 & 10.87 & 21.04 & 13.34 \\
Totals & 100.00 & & 100.00 & & 100.00 & \\
\hline
\end{tabular}
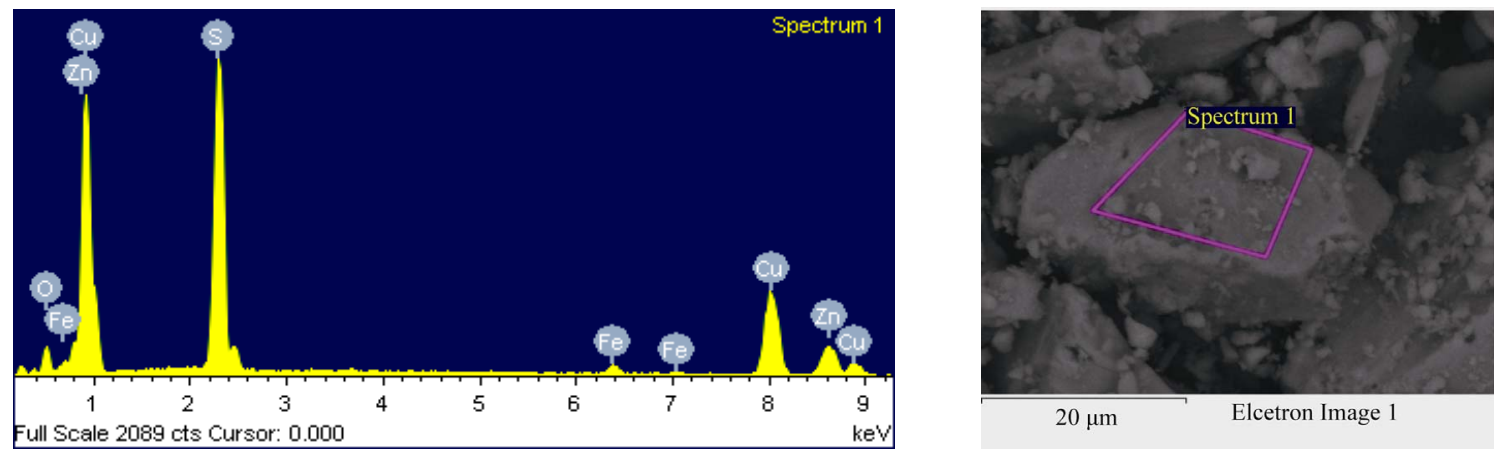

Figure 1. SEM micrograph $(\times 5000)$ and Chemical analysis of the powder as determined by EDAX, shows the presence of copper, sulphur, zinc and iron in a sulphide particle.

\subsection{Industrial Application}

Based on the experimental evidence, obtained with the sulphide precipitation study for copper and cyanide removal from the barren solution after the MerrillCrowe process, this process was installed on a mine site at full scale.

A simplified process flow diagram, which uses sodium sulphide to precipitate copper/silver, and to convert cyanide to $\mathrm{HCN}$ gas, under acid conditions ( $\mathrm{pH} 2$ to 3) is shown in Figure 2.

The system consists of:
- A feed pump located in the precipitation area.

- A line carrying barren solution at a rate of $10 \mathrm{li}$ ters/second, with $1500 \mathrm{ppm}$ of cyanide, 600 to 900 ppm of copper complexes and $0.1 \mathrm{ppm}$ of silver and at a $\mathrm{pH}$ of 11. At this flow rate precipitation of calcium sulphate (scale) would not occur.

- A Serpentine. Barren solution is currently feed along with $\mathrm{Na}_{2} \mathrm{~S}$ solution and sulphuric acid, to a 4 inch plastic pipe section in the shape of a SERPENTINE, (with inside tripack rings mixers as turbulence promoters).

- Three enclosed vacuum vessels of various sizes/ 


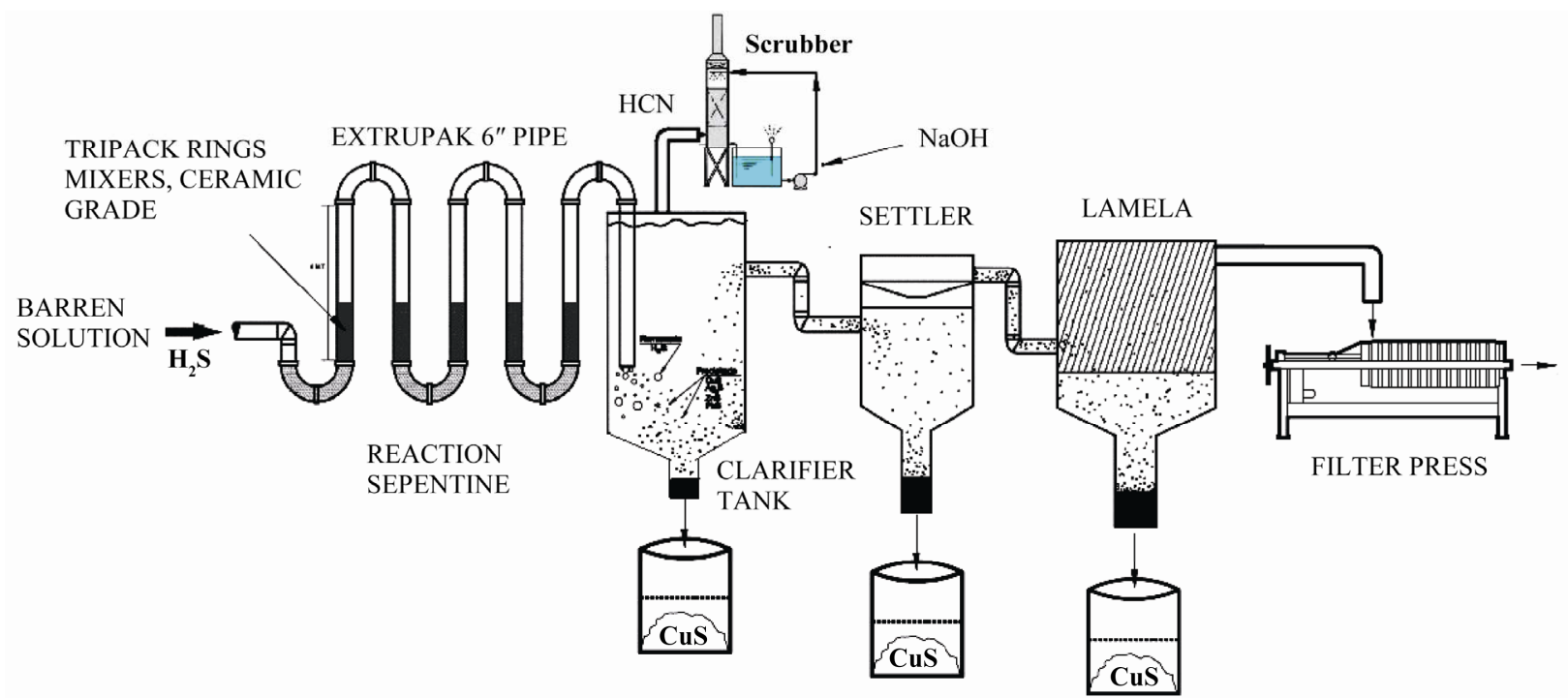

Figure 2. A schematic diagram, showing the SERPENTINE process for $\mathrm{Cu}$, Ag precipitation and cyanide recovering.

shapes meant to be sulfide precipitate collectors. Formulation of poly-electrolyte conditioners that effectively flocculate the fine metal sulfide particles has eliminated the difficulty in separating the precipitate from the discharge and has resulted in sludges that are easily dewatered.

- A HCN gas collection system, located over all vessels with a gas adsorption tower, with sodium hydroxide as the absorbant.

- A pump in the treated barren solution line to feed the filter press.

In five continuous working days the treated solution exited the circuit at a $\mathrm{pH}$ value of 4 , carrying about 0 to 10 ppm of copper and 200 ppm cyanide and was pumped to two neutralizing ( $\mathrm{pH} \mathrm{7)}$ tanks.

\section{Conclusions}

The SERPENTINE system is a viable technology for the recovery of copper, silver and subsequent recovery of $\mathrm{HCN}$ gas by scrubbing in $\mathrm{NaOH}$.

Advantages of the SERPENTIN include: an odor free hermetic process and compact treatment facility, high precipitation rate of copper and silver (99\%) and relatively low operation cost, and also the precipitate is a sellable copper/silver product. However; the main advantages of using the SERPENTIN system are: low energy consumption, production of high grade copper sulphide precipitate in the range of $40 \%$ to $55 \%$ of $\mathrm{Cu}$ with $130 \mathrm{gr} / \mathrm{ton} \mathrm{Ag}$, and recoveries of cyanide of $90 \%$.

\section{Acknowledgements}

The authors acknowledge the support of this project to
Minera William in México, the National Council of Science and Technology (CONACYT) and to the Dirección General de Educación Superior Tecnológica (DGEST) from México.

\section{References}

[1] F. Habashi, "One Hundred Years of Cyanidation Historical Note,” CIM Bulletin, Vol. 80, No. 905, 1987, pp. 108114.

[2] J. R. Parga, J. L. Valenzuela and F. Cepeda, "Pressure Cyanide Leaching for Precious Metals Recovery,” Journal of Metals, Vol. 59, No. 10, 2007, pp. 43-47. doi:10.1007/s11837-007-0130-4

[3] F. Habashi, "Kinetics and Mechanism of Gold and Silver Dissolution in Cyanide Solution,” Bulletin No. 59, Bureau of Mines and Geology, State of Montana, 1967.

[4] J. R. Parga, H. M. Casillas, V. Vazquez and J. L. Valenzuela, "Cyanide Detoxification of Mining Wastewaters with $\mathrm{TiO}_{2}$ Nanoparticles and Its Recovery by Electrocoagulation," Chemical Engineering and Technology, Vol. 32, No. 12, 2009, pp. 1901-1908. doi:10.1002/ceat.200900177

[5] D. M. Muir, “A Review of the Selective Leaching of Gold from Oxidised Copper-Gold Ores with Ammoniacyanide and New Insights for Plant Control and Operation,” Minerals Engineering, Vol. 24, No. 6, 2011, pp. 576-582. doi:10.1016/j.mineng.2010.08.022

[6] C. A. Fleming, "Cyanide Recovery," Developments in Mineral Processing, Vol. 15, 2005, pp. 703-727. doi:10.1016/S0167-4528(05)15029-7

[7] C. W. Lawr, "Cyanide Regeneration as Practiced by Compañia Beneficiadora de Pachuca,” Mexico Technical Publication AIME, Vol. 6, No. 208, 1929, pp. 1-37.

[8] J. R. Parga and D. L. Cocke, "Enhance Cyanide Recovery by Using Air-Sparged Hydrocyclone,” Chemical Engi- 
neering and Technology, Vol. 26, No. 4, 2003, pp. 503507. doi:10.1002/ceat.200390075

[9] Z. M. Shareefdeen, W. Ahmed and A. Aidan, "Kinetics and Modeling of $\mathrm{H}_{2} \mathrm{~S}$ Removal in a Novel Biofilter," Advances in Chemical Engineering and Science, Vol. 1, No. 2, 2011, pp. 72-76. doi:10.4236/aces.2011.12012

[10] A. E. Lewis, "Review of Metal Sulphide Precipitation,"
Hydrometallurgy, Vol. 104, No. 2, 2010, pp. 222-234. doi:10.1016/j.hydromet.2010.06.010

[11] M. Adams, R. Lawrence and M. Bratty, "Biogenic Sulphide for Cyanide Recycle and Copper Recovery in Gold-Copper Ore Processing,” Minerals Engineering, Vol. 21, No. 6, 2008, pp. 509-517. doi:10.1016/j.mineng.2008.02.001 